\title{
Seven new species of the killifish genus Rivulus (Cyprinodontiformes: Rivulidae) from the Paraná, Paraguay and upper Araguaia river basins, central Brazil
}

\author{
Wilson J. E. M. Costa
}

Seven new species of the Rivulus punctatus group collected during recent field studies in central Brazil are described. Rivulus dapazi n. sp., from the upper rio Correntes drainage, rio Paraguay basin, is diagnosed by a unique color pattern of the anal and caudal fins in males; $R$. cyanopterus n. sp., from the upper rio São Lourenço drainage, rio Paraguay basin, is diagnosed by a unique color pattern of the anal fin in both sexes; $R$. rossoi $\mathrm{n}$. sp., from the rio Inhanduí drainage, rio Paraná basin, is diagnosed by a unique color pattern of the caudal fin in males and a reduced number of gill rakers on the first branchial arch; $R$. litteratus n. sp., from the upper rio Araguaia basin, is diagnosed by unique color patterns of flank in males and caudal fin in females; $R$. rutilicaudus n. sp., from the rio Verde drainage in Goiás, rio Paraná basin, is diagnosed by a unique color pattern of the caudal fin in females; R. scalaris n. sp., from the rio Sucuruí, rio Aporé, rio Correntes and rio Taquari drainages, rio Paraná basin, is diagnosed by a unique color pattern of the flank in males; and, R. egens n. sp., from the upper rio Verde drainage in Mato Grosso do Sul, rio Paraná basin, is distinguished by a combination of frontal E-scale pattern and the absence of red marks on the caudal fin in males. Combinations of other color patterns and morphological features, including number of scales of the longitudinal series, number of dorsal, anal, caudal and pectoral fin-rays, relative position of dorsal-fin origin and anal-fin rays, and number of vertebrae, are also useful in identification of the new species, but phylogenetic relationships among them are unknown at the present. A key to identification of species of Rivulus from the rio Paraná-Paraguay basin and adjacent headstreams is provided.

Sete espécies novas do grupo Rivulus punctatus coletadas durante estudos de campo recentes no Brasil central são descritas. Rivulus dapazi sp. n., da drenagem do alto rio Correntes, bacia do rio Paraguai, é diagnosticada por um padrão de colorido exclusivo das nadadeiras anal e caudal em machos; $R$. cyanopterus $\mathrm{sp}$. $\mathrm{n}$., da drenagem do alto rio São Lourenço, bacia do rio Paraguai, é diagnosticada por um padrão de colorido exclusivo da nadadeira anal em ambos sexos; $R$. rossoi sp. n., da drenagem do rio Inhanduí, bacia do rio Paraná, é diagnosticada por um padrão de colorido exclusivo da nadadeira caudal em machos e número reduzido de rastros branquiais no primeiro arco branquial; $R$. litteratus sp. n., da drenagem do alto rio Araguaia, é diagnosticada por um padrão de colorido exclusivo do flanco em machos e da nadadeira caudal em fêmeas; $R$. rutilicaudus sp. n., da drenagem do rio Verde em Goiás, bacia do rio Paraná, é diagnosticada por um padrão exclusivo da nadadeira caudal em fêmeas; $R$. scalaris sp. n., das drenagens do rios Sucuruí, Aporé, Correntes e Taquari, bacia do rio Paraná, é diagnosticada por um padrão de colorido exclusivo do flanco em machos; e, R. egens sp. n., da drenagem do alto rio Verde no Mato Grosso do Sul, bacia do rio Paraná, se distingue por uma combinação de escamação frontal com padrão E e ausência de marcas vermelhas na nadadeira caudal em machos. Combinações de outros padrões de colorido e características morfológicas, incluindo número de escamas da série longitudinal, número de raios das nadadeiras dorsal, anal, caudal e peitoral, posição relativa da origem da nadadeira dorsal e raios da nadadeira anal, e número de vértebras, são também úteis para identificar as novas espécies, mas relações de parentesco entre elas são ainda desconhecidas. Uma chave para identificação das espécies de Rivulus da bacia do rio Paraná-Paraguai e de cabeceiras adjacentes é fornecida.

Key words: Systematics, Cerrado, Neotropic.

Laboratório de Ictiologia Geral e Aplicada, Departamento de Zoologia, Universidade Federal do Rio de Janeiro, Caixa Postal 68049, $21944-$ 970 Rio de Janeiro, RJ, Brazil. e-mail: wcosta@acd.ufrj.br 


\section{Introduction}

Rivulus Poey is the most speciose genus among Neotropical aplocheiloids, comprising about 100 valid species, occurring in the great majority of river basins of Middle and South America (Costa, 1998; 2003a, b, c, d; 2004a, b, c). It is poorly defined as a monophyletic unit among basal lineages of the Rivulidae and diagnosed by an ocellated spot on the caudal fin of females (Costa, 2004c). The greatest diversification of the genus is concentrated on the area comprising river basins of Central America, river basins draining the Guiana Shield (Orinoco, river basins of Guianas and northern tributaries of the Amazonas), and Amazonian lowlands. About 60 species are endemic to this area (Costa, 2003a, c, 2004a, b). However, diversification of Rivulus in the river basins draining the Brazilian Shield (Parnaíba, São Francisco, and ParanáParaguay river basins, southern tributaries of the Amazonas, and smaller coastal Brazilian basins) has been considered remarkably lower, with only 18 endemic species, most of them described in recent years (Costa, 2003a, d). Among them, 11 species, $R$. apiamici Costa, $R$. decoratus Costa, $R$. modestus Costa, $R$. paracatuensis Costa, $R$. parnaibensis Costa, $R$. pictus Costa, $R$. pinima Costa, $R$. punctatus Boulenger, $R$. violaceus Costa, $R$. vittatus Costa, and $R$. zygonectes Myers, are endemic to central and northeastern South America, and comprise a monophyletic assemblage termed the $R$. punctatus species group in previous studies (e. g. Costa, 1995a; 1998).

The $R$. punctatus species group is diagnosed by two synapomorphies: dorsal portion of preopercle short and pointed (vs. long and rounded) and melanophores distinctively concentrated on the margins of the caudal fin, distal edge of dorsal and anal fins, and anterior edge of pelvic fins of females (Costa, 1995a, 1998). All taxa belonging to this clade share some apomorphic conditions with other species assemblages within Rivulus: (1) ventral process of the anguloarticular short and narrow, about one fifth of the angulo-articular length; (2) interhyal minute, not ossified; (3) teeth of the second pharyngobranchial absent; (4) ventral process of the posttemporal absent; (5) seven pelvic-fin rays; and (6) neural prezygapophyses long, about $30 \%$ of neural spine length in anterior caudal vertebrae. Members of the $R$. punctatus group are small fishes, reaching about 20-45 mm SL as adults, and inhabit shallow (about $5-30 \mathrm{~cm}$ deep), floodplains adjacent to rivers and streams. Five species of the $R$. punctatus species group have been recorded for the rio Paraná and rio Paraguay basins. Rivulus apiamici, R. pictus, $R$. pinima, and $R$. vittatus are endemic to the upper rio Paraná basin, central Brazilian plateau. Rivulus punctatus is distributed in the rio Paraguay lowlands in Brazil, Bolivia, Paraguay, and Argentina (Costa, 1989; 1995a; 2003a).

Except for the Pantanal lowlands, the relief of central Brazil in the rio Paraná-Paraguay basin is mainly characterized by a series of mesa formations with extensive karstic areas. Altitudes vary from about $250 \mathrm{~m}$, at the floodplains of middle rio Paraná, to about $1,000 \mathrm{~m}$, on the highest plains of the central plateau. The river courses are often interrupted by waterfalls and sometimes present subterranean sections. This topography isolates populations of Rivulus, which are restricted to plain rivers and streams with flooded margins, where individuals uniquely inhabit the shallow marginal places. Recent explorations of small streams in areas of the Cerrado, the savanna-like vegetation of the central Brazilian plateau, revealed seven still unnamed species, which are herein described.

\section{Materials and Methods}

Measurements and counts follow Costa (1995b). Measurements are presented as percents of standard length (SL), except for head measurements that are expressed as percents of head length. Fin-ray counts include all elements; counts of pectoral, pelvic and caudal-fin rays, gill rakers, and vertebrae were made only on cleared and stained (c\&s) specimens, prepared in accordance with Taylor \& Van Dyke (1985). For the vertebral counts, the compound caudal centrum was counted as a single element. Nomenclature for frontal squamation follows Hoedeman (1958), and for cephalic neuromasts follows Costa (2001). Abbreviations for institutions are: MZUSP Museu de Zoologia, Universidade de São Paulo, São Paulo; and, UFRJ - Universidade Federal do Rio de Janeiro, Rio de Janeiro.

\section{Results}

\section{Key to the species of Rivulus from the Paraná-Paraguay river basins and adjacent headwaters}

1. Never distinctive stripe along midline; often red bars on caudal fin in male (except in $R$. pinima and $R$. egens); frontal squamation usually E-patterned (except in R. litteratus); flank with intense iridescent colors in male, usually contrasting metallic blue to greenish blue on middle of flank with light purplish blue above anal fin and brownish golden on anterior dorsolateral portion of body

1'. Always distinctive stripe along midline, more conspicuous when exposed to light, but also visible in preserved specimens; never red bars on caudal fin; frontal squamation F-patterned, except in a few specimens of $R$. dapazi with E-patterned squamation; iridescent colors present or not, when present not intense, whole flank metallic green

2. Scales on longitudinal series 30-32; oblique rows of red dots on flank; anal fin never with orange distal stripe; caudal-fin never with entire margin dark orange with black ventral outline

2'. Scales on longitudinal series 34-35; oblique red bars on flank; anal fin with dark orange distal stripe in male; entire caudal-fin margin dark orange with black ventral outline in male ............................................................ R. dapazi

3. Caudal-fin rays 27-29; never anal fin blue with red bars; caudal fin with distinctive colors at least on dorsal and anal fin margins in male 4 
3'. Caudal-fin rays 29-31; whole anal fin blue with oblique red bars in both sexes; caudal fin yellow, without distinctive colors on margins in male $R$. cyanopterus

4. Gill rakers on first arch 1+6; narrow orange stripe on anterior portion of dorsal and ventral margins of caudal fin in male R. rossoi

4'. Gill rakers on first arch 1+8; white stripe on entire caudal fin margin in male R. punctatus

5. Frontal squamation E-patterned ...... ................ 6

5'. Frontal squamation F-patterned R. litteratus

6. 29-32 scales on the longitudinal series .......................... 11

6'. 32-36 scales on the longitudinal series ............................ 7

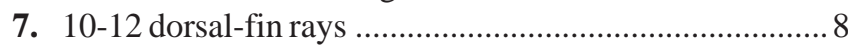

7'. 8-10 dorsal-fin rays . R. pictus

8. Ventral portion of caudal fin with a distinctive dark yellowish gray zone ...9 9

8'. Ventral portion of caudal fin without a distinctive dark colored zone 10

9. Dorsal and anal fins rounded in male; tip of pelvic fin reaching between urogenital papilla and base of first anal-fin ray in male; never oblique red bars on flank; no dark marks on opercular and humeral regions; red dots or no red marks on caudal fin in males, dark gray spots in female R. pinima

9'. Dorsal and anal fins pointed in male; tip of pelvic fin reaching between base of second and fourth anal-fin rays in male; oblique red bars on flank; dark reddish brown marks on opercular and humeral regions; broad bars on caudal fin, red in males, dark gray in female

$R$. vittatus

10. Dorsal-fin origin at vertical between base of eighth and ninth anal-fin ray; flank light metallic blue with narrow red chevron-like oblique bars in males; caudal fin dark orangish red in females.

R. rutilicaudus

$1^{\prime}$. Dorsal-fin origin at vertical between base of seventh and eighth anal-fin ray; flank intense metallic blue with broad red chevron-like oblique bars in males; caudal fin pale yellow in females $R$. scalaris

11. 11-12 pectoral-fin rays; caudal fin with narrow red bars in males, and dark gray bars in females R. apiamici

11'.13-14 pectoral-fin rays; caudal fin without red marks in males, and with vertical rows of dark gray spots in females

R. egens

\section{Rivulus dapazi, new species}

Fig. 1

Holotype. UFRJ 5915, male, 24.3 mm SL; Brazil: Estado de Mato Grosso do Sul: Sonora, córrego Confusão, tributary to rio Correntes, rio Paraguay basin, 17'33'56.4'S 54 44'23.8'W, altitude 411m; W. J. E. M. Costa, C. P. Bove \& B. B. Costa, 22 Jul 2003. Paratypes. Brazil: Estado de Mato Grosso do Sul: Sonora: rio Paraguay basin: UFRJ 5916, 3 females, 21.9-22.8 mm SL; UFRJ 5917, 1 male, $20.7 \mathrm{~mm}$ SL, 1 female, $18.7 \mathrm{~mm}$ SL (c\&s); collected with the holotype. UFRJ 5918, 5 males, 20.9-31.7 mm SL, 3 females, 20.9-24.9 mm SL; UFRJ 5919, 2 males, 21.9-24.1 mm SL (c\&s); córrego do Burro, tributary to rio Correntes; R. C. da Paz, 6 Feb 2003. Estado de Mato Grosso: Itiquira: rio Paraguay basin. UFRJ 5920, 7 males, 14.2-22.1 mm SL, 5 females, 13.5-21.6 mm SL; UFRJ 5921, 2 males, 23.0-26.7 mm SL, 1 female, $19.1 \mathrm{~mm} \mathrm{SL}$ (c\&s); rio Comprido, a tributary to rio Correntes; R. C. da Paz, 5 Feb 2003. UFRJ 5922, 1 female, 21.4 mm SL; right bank of rio Correntes; R. C. da Paz, 4 Feb 2003. MCP 36120, 5 males, 16.6-19.1 mm SL, 4 females, 15.6-21.5 mm SL; right bank of rio Comprido, a tributary to rio Correntes; $\mathrm{R}$. C. da Paz, 4 Feb 2003. UFRJ 5924, 2 males, 19.1-20.5 mm SL, 1 female, 22.0 mm SL; rio Comprido; R. C. da Paz, 6 Feb 2003.

Diagnosis. Distinguished from all other species of the $R$. punctatus group in having an anal fin with an orange distal stripe ( $v s$. orange distal stripe absent) and caudal fin with marginal region dark orange with black ventral outline in males (vs. never a similar pattern). Differs from all other species from the Paraná-Paraguay basin by the combination of the following features: flank with chevron-like red lines ( $v s$. oblique rows of red dots), flank with dark gray stripe along midline ( $v s$. stripe absent), and 34-35 scales on the longitudinal series ( $v s$. 30-32 as in all other species of the rio Paraguay basin).

Description. Morphometric data in Table 1. Largest specimen $31.7 \mathrm{~mm} \mathrm{SL}$, male. Dorsal profile slightly convex from snout to end of dorsal-fin base, approximately straight on caudal peduncle. Ventral profile convex on head, almost straight from anterior portion of venter to end of anal-fin base, nearly straight along caudal peduncle. Body slender, approximately cylindrical anteriorly, slightly deeper than wide, to compressed posteriorly. Greatest body depth at level of pelvic-fin base.

Dorsal and anal fins rounded. Caudal fin oval. Pectoral fin rounded, posterior margin on vertical just anterior to pelvicfin base. Tip of pelvic fin reaching between urogenital papilla and base of first anal-fin ray in male, and urogenital opening in female. Pelvic-fin bases in close proximity. Dorsal-fin origin on vertical through base of 8th or 9th anal-fin ray, and between neural spines of 18th and 19th vertebrae. Anal-fin origin between pleural ribs of 13th and 15th vertebrae. Dorsalfin rays 10-11; anal-fin rays $14-15$; caudal-fin rays $30-31$; pectoral-fin rays 13-14; pelvic-fin rays 6-7.

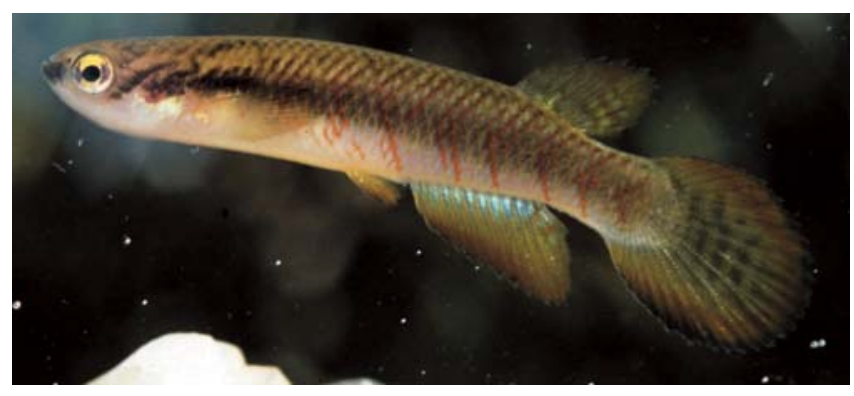

Fig. 1. Rivulus dapazi, UFRJ 5915, male, holotype, $24.3 \mathrm{~mm}$ SL (minutes after collection); Brazil: Mato Grosso do Sul: Sonora. Photo by W. J. E. M. Costa. 
Table 1. Morphometric data of the holotype (H, male) and paratypes of Rivulus dapazi.

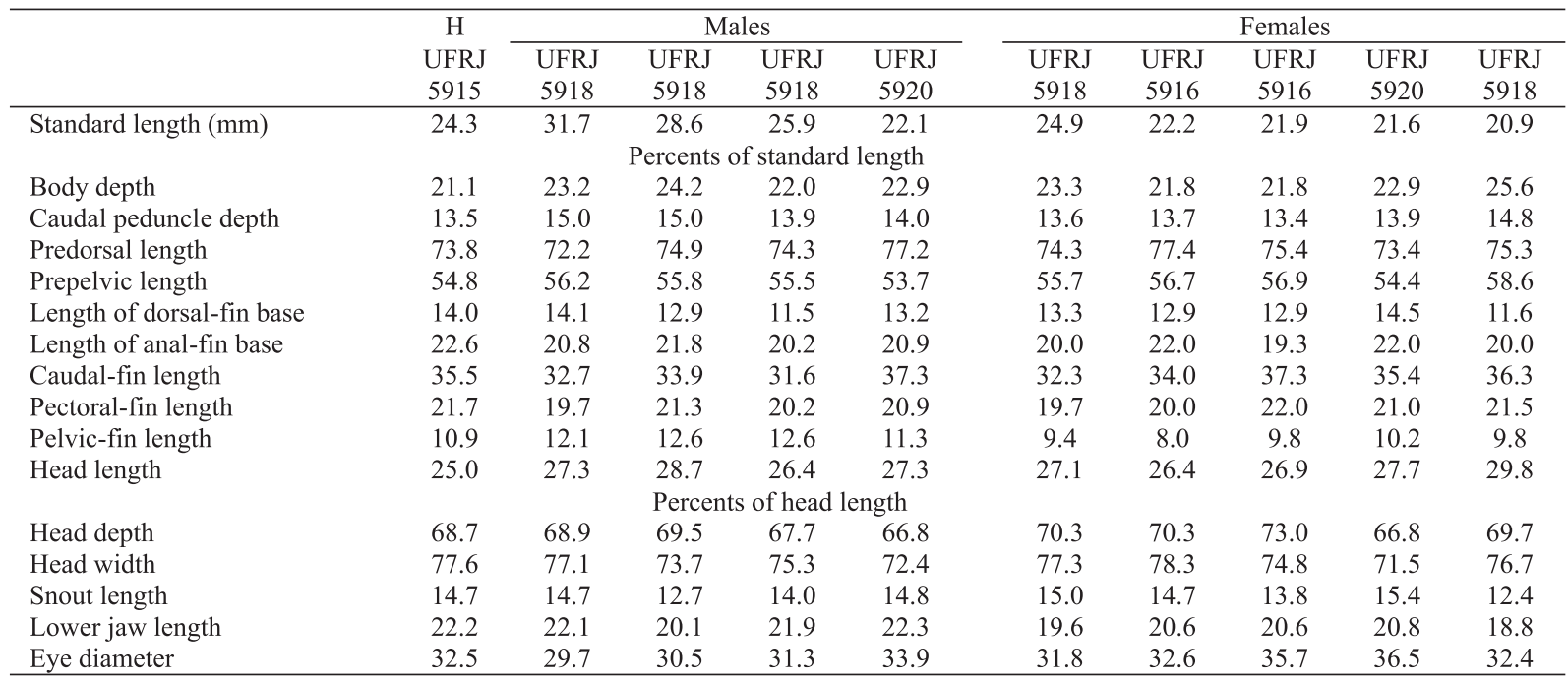

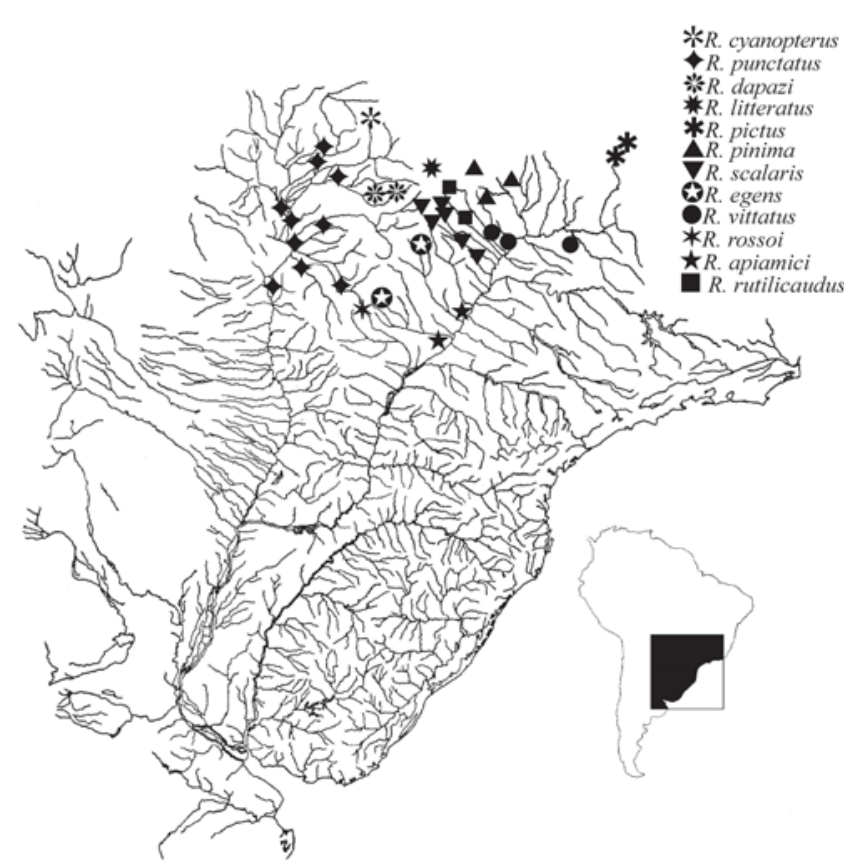

Fig. 2. Geographic distribution of species of the genus Rivulus in the Paraná, Paraguay, and upper Araguaia river basins, central Brazil.

Scales large, cycloid. Trunk scaled; head scaled except on anteroventral surface. Body scales slightly extending over caudal-fin base; no scales on dorsal and anal fins. Frontal squamation usually F-patterned, sometimes E-patterned; Escales not overlapping medially; scales arranged in circular pattern around central A-scale without exposed margins. Longitudinal series of scales 34-35; transverse series of scales 8; scale rows around caudal peduncle 16. Contact organs absent. Supraorbital neuromasts $3+3$. Six branchiostegal rays. Gill rakers of first branchial arch 1+7-8. One to three vomerine teeth. Total vertebrae 30-31.

Coloration. Male: Side of body light brown dorsally, light gray ventrally, with oblique, narrow chevron-like red bars with vertex anteriorly directed, and dark gray to dark brown stripe between eye and caudal-fin base, anterior portion of stripe usually black, entire stripe darker when exposed to light; faint laterodorsal brown spots on anterior portion of body. Dorsum light brown, venter white. Two black oblique bars on postorbital region. Infraorbital region and ventral surface of head white. Lower jaw black. Iris light yellow. Dorsal fin dark yellow with three faint oblique gray bars. Anal fin dark yellow, with red dots on posterobasal region, dark orange distal stripe, and narrow light blue base. Caudal fin dark yellow, marginal region dark orange with black outline, wider on ventral margin; faint gray bars on middle of fin. Pelvic fin dark yellow. Pectoral fin hyaline.

Female: Side of body light brown above, white below lateral midline, with dark brown stripe on lateral midline; oblique, narrow chevron-like dark red lines, with vertex anteriorly directed, on entire flank; laterodorsal gray spots on anterior portion of body. Dorsum light brown, venter white. Postorbital region light brown with oblique dark brown bars. Infraorbital region and ventral surface of head white. Lower jaw dark gray. Iris light yellow. Dorsal fin pale yellow with two oblique gray bars, and dark gray distal stripe. Anal fin pale yellow, with dark gray distal stripe. Caudal fin hyaline, pale white on dorsal and pale yellow on ventral portion, with four dark gray bars on central portion; dark gray zone along fin margin; round black spot on dorsobasal portion of fin, not reaching fin margin; two small light yellow spots dorsally and ventrally adjacent to black caudal spot. Paired fins hyaline; anterior margin of pelvic fin dark gray.

Distribution. Upper section of the rio Correntes drainage, rio Paraguay basin, central Brazil (Fig. 2).

Etymology. The name dapazi in honor of the ichthyologist Ricardo Campos da Paz, the first collector of the new species. 


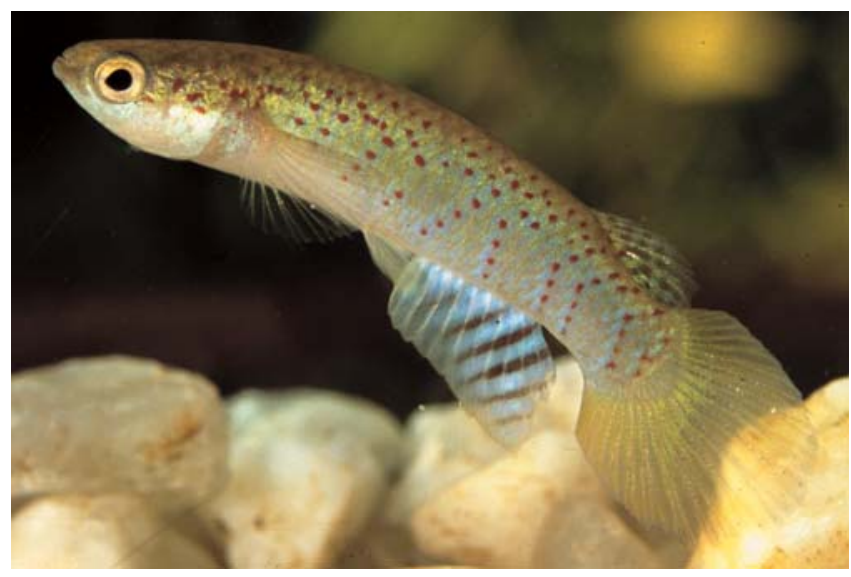

Fig. 3. Rivulus cyanopterus, UFRJ 5911, male, holotype, 27.6 $\mathrm{mm}$ SL (one day after collection); Brazil: Mato Grosso: Jaciara. Photo by W. J. E. M. Costa.

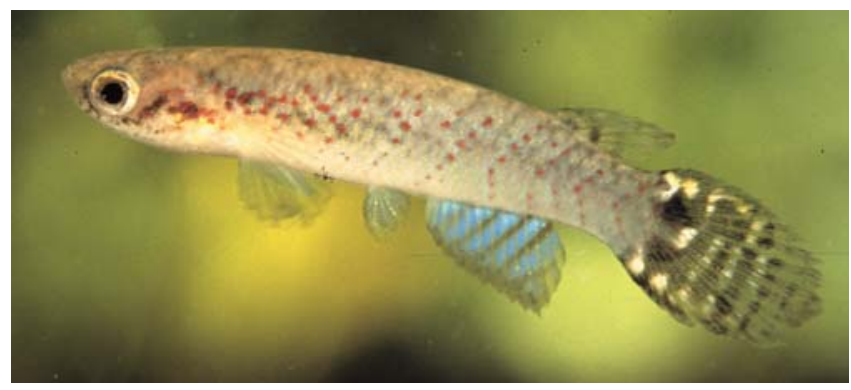

Fig. 4. Rivulus cyanopterus, UFRJ 5912, female, paratype, $21.4 \mathrm{~mm}$ SL (one day after collection); Brazil: Mato Grosso: Jaciara. Photo by W. J. E. M. Costa.

\section{Rivulus cyanopterus, new species} Figs. 3-4

Holotype. UFRJ 5911, male, 27.6 mm SL; Brazil: Estado de Mato Grosso: Jaciara, swamp close to rio Tenente Amaral, a tributary to upper rio São Lourenço, rio Paraguay basin, 15'58'48.9”S 5457'20.0”'W, altitude 246 m; W. J. E. M. Costa, C. P. Bove \& B. B. Costa, 21 Jul 2003.

Paratypes. UFRJ 5912, 1 male, 25.5 mm SL, 2 females, 20.921.4 mm SL; UFRJ 5913, 22 males, 15.3-26.4 mm SL, 12 females, 16.7-24.2 mm SL, 2 juveniles, 9.6-12.1 mm SL; MCP 36121, 5 males, 17.6-22.9 mm SL, 3 females, 17.2-19.9 mm SL; UFRJ 5914, 3 males, 21.7-24.9 mm SL, 2 females, 20.9-21.1 mm SL (c\&s); collected with the holotype.

Diagnosis. Distinguished from all other species of the $R$. punctatus group in possessing an entirely anal fin blue with oblique red bars in both sexes ( $v s$. anal fin yellow with blue base, red dots or bars restricted to the basal portion) and caudal-fin base with two large, round black spots vertically arranged in females ( $v s$. a single spot in all other species, except sometimes in $R$. punctatus with two smaller spots). Differs from all congeners from the rio Paraná-Paraguay basin by the following combination of features: flank with oblique rows of red dots ( $v s$. oblique red bars), flank with dark gray stripe along midline ( $v s$. no distinctive dark stripe), and entire caudal fin yellow, without distinctive colors on margins in males ( $v s$. caudal-fin margins with distinctive color stripe in all other species of the rio Paraguay basin).

Description. Morphometric data in Table 2. Largest specimen $27.6 \mathrm{~mm}$ SL, male. Dorsal profile slightly convex from snout to end of dorsal-fin base, approximately straight to gently concave on caudal peduncle. Ventral profile convex on head, almost straight from anterior portion of venter to end of analfin base, nearly straight to slightly concave along caudal peduncle. Body slender, subcylindrical anteriorly, slightly deeper than wide, to compressed posteriorly. Greatest body depth at level of pelvic-fin base.

Dorsal fin rounded. Anal fin slightly pointed in male, rounded to slightly pointed in female. Caudal fin oval. Pectoral fin rounded, posterior margin on vertical through pelvic-fin base in male, just anterior to it in female. Tip of pelvic fin reaching between base of first and third anal-fin ray in male, and urogenital opening in female. Pelvic-fin bases in close proximity. Dorsal-fin origin on vertical through base of 9th or 10th anal-fin ray, and between neural spines of 18 th and 20th vertebrae. Anal-fin origin between pleural ribs of 13 th and 15 th vertebrae. Dorsal-fin rays 8-9; anal-fin rays 13-14; caudal-fin rays 29-31; pectoral-fin rays 13-14; pelvicfin rays 7 .

Scales large, cycloid. Trunk scaled; head scaled except on anteroventral surface. Body scales slightly extending over caudal-fin base; no scales on dorsal and anal fins. Frontal squamation F-patterned; E-scales not overlapping medially; scales arranged in circular pattern around central A-scale without exposed margins. Longitudinal series of scales 30-32; transverse series of scales 8; scale rows around caudal peduncle 16 . Contact organs absent. Supraorbital neuromasts $3+3$. Six branchiostegal rays. Gill rakers of first branchial arch $1+7$. Two vomerine teeth. Total vertebrae 31-32.

Coloration. Male: Side of body metallic green with oblique chevron-like rows of red dots, with vertex anteriorly directed; faint laterodorsal brown spots on anterior portion of body; dark gray stripe between eye and caudal-fin base, darker when exposed to light. Dorsum light brown, venter white. Postorbital region metallic green with red dots. Infraorbital region and ventral surface of head white. Lower jaw dark gray. Iris light yellow. Dorsal fin light greenish yellow with 5-7 oblique dark red bars. Anal fin light blue with 6-8 oblique dark red bars. Caudal fin light greenish yellow. Pelvic fin pale yellow. Pectoral fin hyaline.

Female: Side of body light gray with oblique chevronlike rows of dark red dots, with vertex anteriorly directed; laterodorsal gray spots on anterior portion of body; dark gray stripe between eye and caudal-fin base, darker when fish is exposed to light. Dorsum light brown, venter white. Postorbital region gray with red reticulation. Infraorbital re- 
Table 2. Morphometric data of the holotype (H, male) and paratypes of Rivulus cyanopterus.

\begin{tabular}{|c|c|c|c|c|c|c|c|c|c|c|}
\hline & \multirow{3}{*}{$\begin{array}{c}\mathrm{H} \\
\text { UFRJ } \\
5911 \\
\end{array}$} & \multicolumn{4}{|c|}{ Males } & \multicolumn{5}{|c|}{ Females } \\
\hline & & UFRJ & UFRJ & UFRJ & UFRJ & UFRJ & UFRJ & UFRJ & UFRJ & UFRJ \\
\hline & & 5913 & 5912 & 5913 & 5913 & 5913 & 5913 & 5912 & 5912 & 5913 \\
\hline Standard length $(\mathrm{mm})$ & 27.6 & 26.4 & 25.5 & 25.4 & 22.9 & 24.2 & 21.5 & 21.4 & 20.9 & 19.7 \\
\hline \multicolumn{11}{|c|}{ Percents of standard length } \\
\hline Body depth & 22.3 & 23.4 & 21.4 & 20.7 & 21.2 & 21.0 & 21.4 & 21.4 & 21.0 & 21.4 \\
\hline Caudal peduncle depth & 14.8 & 15.5 & 13.6 & 13.7 & 13.5 & 13.5 & 13.3 & 14.4 & 13.7 & 14.3 \\
\hline Predorsal length & 75.9 & 75.7 & 78.0 & 75.8 & 76.9 & 75.0 & 76.4 & 77.2 & 77.2 & 78.6 \\
\hline Prepelvic length & 53.0 & 55.8 & 53.8 & 52.5 & 54.4 & 52.9 & 54.7 & 55.9 & 56.3 & 54.7 \\
\hline Length of dorsal-fin base & 9.7 & 10.1 & 11.5 & 9.7 & 10.4 & 9.9 & 9.4 & 10.9 & 10.5 & 9.4 \\
\hline Length of anal-fin base & 21.0 & 21.6 & 23.1 & 21.6 & 21.2 & 20.0 & 19.5 & 21.5 & 21.5 & 21.1 \\
\hline Caudal-fin length & - & 41.1 & 39.4 & 41.1 & 39.8 & 34.3 & 35.4 & 36.9 & 36.2 & 39.2 \\
\hline Pectoral-fin length & 21.7 & 22.9 & 21.3 & 21.5 & 21.9 & 21.2 & 21.1 & 22.5 & 20.8 & 24.3 \\
\hline Pelvic-fin length & 12.6 & 13.9 & 13.3 & 12.1 & 12.7 & 10.2 & 9.9 & 10.7 & 11.2 & 12.1 \\
\hline Head length & 26.5 & 27.6 & 27.8 & 27.5 & 27.3 & 25.7 & 28.3 & 27.8 & 28.3 & 29.4 \\
\hline \multicolumn{11}{|c|}{ Percents of head length } \\
\hline Head depth & 66.3 & 65.6 & 66.2 & 62.0 & 64.7 & 67.5 & 64.7 & 63.0 & 62.9 & 63.6 \\
\hline Head width & 79.5 & 81.8 & 73.2 & 72.8 & 80.1 & 81.8 & 75.9 & 77.8 & 74.4 & 72.4 \\
\hline Snout length & 12.9 & 13.0 & 13.4 & 13.0 & 13.9 & 14.8 & 13.1 & 11.9 & 12.8 & 13.1 \\
\hline Lower jaw length & 21.6 & 17.3 & 20.4 & 17.9 & 20.0 & 18.3 & 20.2 & 18.0 & 20.6 & 17.9 \\
\hline Eye diameter & 30.2 & 32.4 & 30.6 & 33.0 & 32.7 & 34.4 & 35.5 & 33.8 & 35.8 & 35.5 \\
\hline
\end{tabular}

gion and ventral surface of head white. Lower jaw dark gray. Iris light yellow. Dorsal fin pale yellow with 5-7 oblique dark gray bars, and dark gray distal stripe. Anal fin light blue with 6-8 oblique dark red bars, and dark gray distal stripe. Caudal fin white with 3-5 dark gray bars or vertical rows of spots; dark gray zone along fin margin; two round black spots vertically arranged on basal portion, not contacting fin margin. Paired fins hyaline; anterior margin of pelvic fin dark gray.

Distribution. Known only from the type locality, floodplains of rio Tenente Amaral, upper rio São Lourenço drainage, rio Paraguay basin, central Brazil (Fig. 2).

Etymology. From the Greek kyanos (blue) and pteron (fin) referring to the blue anal fin occurring in both sexes of the new species.

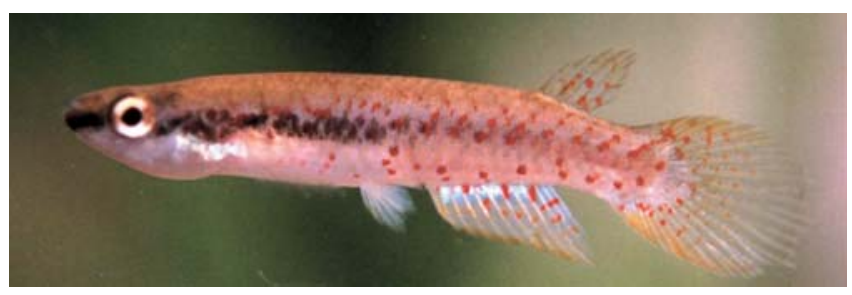

Fig. 5. Rivulus rossoi, UFRJ 5976, male, holotype, $18.9 \mathrm{~mm} \mathrm{SL}$ (five days after collection); Brazil: Mato Grosso do Sul: Campo Grande. Photo by W. J. E. M. Costa.

\section{Rivulus rossoi, new species}

Fig. 5

Holotype. UFRJ 5976, male, 18.9 mm SL; Brazil: Estado de Mato Grosso do Sul: Município de Campo Grande: stream at the road BR-060, $21.5 \mathrm{~km} \mathrm{SW}$ from Campo Grande, rio
Inhanduí drainage, rio Paraná basin, about 2040'S 54²0'W, altitude about 500 m; A. Rosso, 30 Mar 2004.

Paratypes. UFRJ 5977, 6 males, 17.2-21.5 mm SL, 1 female, 16.9 mm SL; UFRJ 5978, 2 males, 16.5-18.8 mm SL, 2 females, 16.5$17.2 \mathrm{~mm}$ SL (c\&s); collected with the holotype. UFRJ 5923, 1 female, $19.7 \mathrm{~mm}$ SL; MCP 36122; 2 males, 17.8-18.1 mm SL; same locality and collector, 7 Mar 2004.

Diagnosis. Distinguished from all other species of the $R$. punctatus group by having $1+6$ Gill rakers on the first branchial arch (vs. $1+7-8)$ and a unique color pattern of caudal fin in males, in which the fin is hyaline, the anterior half with red dots and narrow light orange stripe on the dorsal and ventral margins ( $v s$. never a similar color pattern). Differs from all congeners from the rio Paraná basin by having oblique rows of red dots ( $v s$. oblique red bars or horizontal rows of red dots) on the flank, dark gray stripe along midline of flank ( $v s$. no distinctive dark stripe), 28-29 caudal-fin rays ( $v s .30-34)$.

Description. Morphometric data in Table 3. Largest specimen $19.7 \mathrm{~mm} \mathrm{SL}$, male. Dorsal profile weakly convex from snout to end of dorsal-fin base, approximately straight to gently concave on caudal peduncle. Ventral profile convex on head, slightly convex from anterior portion of venter to end of analfin base, nearly straight to slightly concave along caudal peduncle. Body slender, subcylindrical anteriorly, slightly deeper than wide, to compressed posteriorly. Greatest body depth at level of pelvic-fin base.

Dorsal fin rounded to slightly pointed in male, rounded in female. Anal fin pointed in male, rounded to slightly pointed in female. Caudal fin rounded. Pectoral fin rounded, posterior margin on vertical through pelvic-fin base in male, just anterior to it in female. Tip of pelvic fin reaching between urogenital papilla and anal-fin origin in male, and between anus and urogenital opening in female. Pelvic-fin bases in close proximity. Dorsal-fin origin on vertical through 
Table 3. Morphometric data of the holotype (H, male) and paratypes of Rivulus rossoi.

\begin{tabular}{|c|c|c|c|c|c|c|c|}
\hline & \multirow{3}{*}{$\begin{array}{c}\mathrm{H} \\
\text { UFRJ } \\
5976\end{array}$} & \multicolumn{4}{|c|}{ Males } & \multicolumn{2}{|c|}{ Females } \\
\hline & & UFRJ & $\mathrm{MCP}$ & UFRJ & MCP & UFRJ & UFRJ \\
\hline & & 5977 & 36122 & 5977 & 36122 & 5977 & 5977 \\
\hline Standard length $(\mathrm{mm})$ & 18.9 & 21.5 & 18.1 & 18.0 & 17.8 & 19.7 & 16.9 \\
\hline \multicolumn{8}{|c|}{ Percents of s tandard length } \\
\hline Body depth & 19.1 & 19.0 & 19.3 & 20.4 & 18.3 & 18.4 & 19.3 \\
\hline Caudal peduncle depth & 12.9 & 12.8 & 12.5 & 13.0 & 12.3 & 11.8 & 12.7 \\
\hline Predorsal length & 79.3 & 77.2 & 79.3 & 78.0 & 79.3 & 80.0 & 77.4 \\
\hline Prepelvic length & 53.5 & 55.4 & 53.3 & 53.8 & 53.6 & 56.0 & 53.2 \\
\hline Length of dorsal-fin base & 9.8 & 9.2 & 10.8 & 9.6 & 10.0 & 8.5 & 9.6 \\
\hline Length of anal-fin base & 21.8 & 20.3 & 21.0 & 21.1 & 21.7 & 20.2 & 21.4 \\
\hline Caudal-fin length & 38.4 & 36.8 & 38.5 & 38.3 & 37.6 & 38.5 & 33.7 \\
\hline Pectoral-fin length & 23.8 & 23.7 & 20.7 & 22.7 & 22.8 & 20.3 & 21.5 \\
\hline Pelvic-fin length & 12.3 & 11.0 & 12.5 & 12.0 & 11.8 & 10.6 & 10.5 \\
\hline Head length & 28.5 & 26.8 & 27.1 & 27.5 & 27.9 & 27.8 & 26.5 \\
\hline \multicolumn{8}{|c|}{ Percents of head length } \\
\hline Head depth & 55.9 & 61.0 & $59.7^{\circ}$ & 60.8 & 59.1 & 61.0 & 64.5 \\
\hline Head width & 66.1 & 68.7 & 70.7 & 73.5 & 68.5 & 66.3 & 75.9 \\
\hline Snout length & 14.1 & 14.6 & 14.7 & 12.1 & 13.9 & 15.7 & 13.8 \\
\hline Lower jaw length & 19.8 & 20.0 & 19.3 & 18.8 & 18.1 & 19.9 & 18.3 \\
\hline Eye diameter & 35.4 & 35.5 & 36.5 & 37.6 & 34.5 & 33.5 & 37.5 \\
\hline
\end{tabular}

base of 10th or 11th anal-fin ray, and between neural spines of 19th and 21st vertebrae. Anal-fin origin between pleural ribs of 13th and 14th vertebrae. Dorsal-fin rays 8-9; anal-fin rays $13-14$; caudal-fin rays $28-29$; pectoral-fin rays 13 ; pelvic-fin rays 7.

Scales large, cycloid. Trunk scaled; head scaled except on its anteroventral surface. Body scales slightly extending over caudal-fin base; no scales on dorsal and anal fins. Frontal squamation F-patterned; E-scales not overlapping medially; scales arranged in circular pattern around central A-scale without exposed margins. Longitudinal series of scales 31-32; transverse series of scales 8; scale rows around caudal peduncle 16. Contact organs absent. Supraorbital neuromasts $3+3$. Six branchiostegal rays. Gill rakers of first branchial arch $1+6$. One vomerine teeth. Total vertebrae 30 .

Coloration. Male: Side of body light purplish brown with oblique chevron-like rows of red dots, with vertex anteriorly directed; laterodorsal gray spots on anterior portion of body; dark gray stripe between eye and caudal-fin base, darker on anterior portion and when exposed to light. Dorsum light brown, venter white. Postorbital region silver. Infraorbital region and ventral surface of head white. Lower jaw dark gray to black. Iris light yellow. Dorsal fin hyaline with red dots. Anal fin light yellow, base bright blue with red dots. Caudal fin hyaline with red dots on anterior half, dots larger on dorsal and ventral portions; narrow light orange stripe on anterior portion of dorsal and ventral edges. Pelvic fin pale yellow. Pectoral fin hyaline.

Female: Side of body light brown with oblique rows of dark reddish brown small spots; laterodorsal gray spots on anterior portion of body; dark gray to black stripe between eye and caudal-fin base, darker when exposed to light. Dorsum light brown, venter white. Postorbital region gray. Infraorbital region and ventral surface of head white. Lower jaw dark gray to black. Iris light yellow. Dorsal fin hyaline with pale red dots; dark gray distal stripe. Anal fin light yellow, base blue with pale red dots, and dark gray distal stripe. Caudal fin hyaline with dark gray small spots; dark gray zone along fin margin; round black spot on dorsobasal portion, not contacting fin margin. Paired fins hyaline; anterior margin of pelvic fin dark gray.

Distribution. Known only from the type locality, upper rio Inhanduí drainage, rio Paraná basin, central Brazil (Fig. 2).

Etymology. The name rossoi after Aldovan Rosso, the first collector of the new species.

\section{Rivulus litteratus, new species} Figs. 6-7

Rivulus sp. - Lacerda, 1989: 25 (Ponte Branca, rio Araguaia, central Brazil).

Rivulus pictus (non Costa, 1989). - Costa et al., 2003: 143 (misidentification of specimens from Alto Araguaia).

Holotype. UFRJ 5956, male, 26.9 mm SL; Brazil: Estado de Mato Grosso: Município de Alto Araguaia, córrego do Sapo, upper rio Araguaia basin, road MT-100, $31 \mathrm{~km} \mathrm{~S}$ of Alto Araguaia,

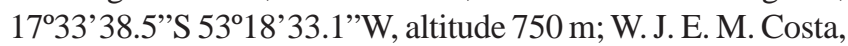
B. B. Costa and C. P. Bove, 14 Jan 2004.

Paratypes. Brazil: Estado de Mato Grosso: Município de Alto Araguaia, upper rio Araguaia basin: UFRJ 5957; 3 males, 23.4-28.1 mm SL, 4 females, 16.5-27.4 mm SL; collected with the holotype. UFRJ 5837, 12 males, 18.8-24.1 $\mathrm{mm}$ SL, 28 females, 14.2-24.3 mm SL, 1 juvenile, $12.4 \mathrm{~mm} \mathrm{SL}$; MCP 36123, 4 males, 19.1-20.2 mm SL, 6 females, 20.1-21.8 mm SL; UFRJ 5958, 3 males, 22.2-23.8 mm SL, 3 females, 22.3-23.9 mm SL (c\&s); same locality; W. J. E. M. Costa, S. M. Q. Lima, D. F. Belote and E. S. Araújo, 6 Apr 2002. MZUSP 73303, 6 males, 23.5-26.6 mm SL, 9 females, 24.8- 
$30.2 \mathrm{~mm}$ SL; córrego Tapera, km 482.37 of the Ferronorte railway, $17^{\circ} 22^{\prime} 18^{\prime}$ 'S 5314'25'W; C. L. R. Moreira and F. C. T. Lima, 18 May 2001.

Diagnosis. Distinguished from all other species of the $R$. punctatus group by the unique color pattern on the flank in males, with red marks variable in shape, highly overlapped (vs. never a similar color pattern), and caudal fin with dark gray stripe posterior to caudal spot in females (vs. stripe absent). Also distinguished from all other members of the $R$. punctatus group by the combination of the following features: frontal squamation F-patterned ( $v s$. Epatterned), flank with striking iridescent colors in male, contrasting metallic blue to greenish blue on middle of flank with light purplish blue above anal fin and brownish golden on anterior dorsolateral portion of body ( $v s$. never a similar color pattern), no distinctive dark stripe along midline of flank ( $v s$. stripe present); red bars on caudal fin in males (vs. bars absent).

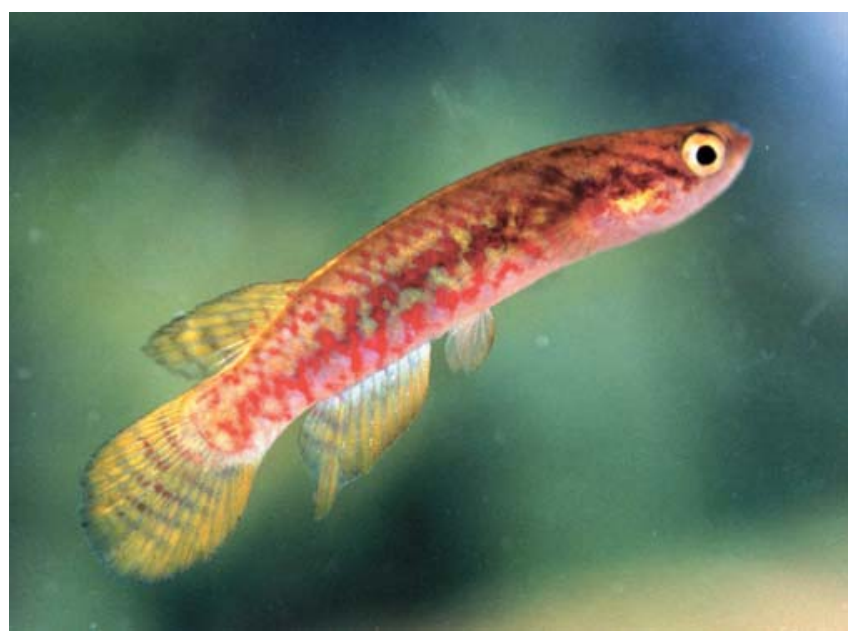

Fig. 6. Rivulus litteratus, UFRJ 5956, male, holotype, $26.9 \mathrm{~mm}$ SL (one day after collection); Brazil: Mato Grosso: Alto Araguaia. Photo by W. J. E. M. Costa.

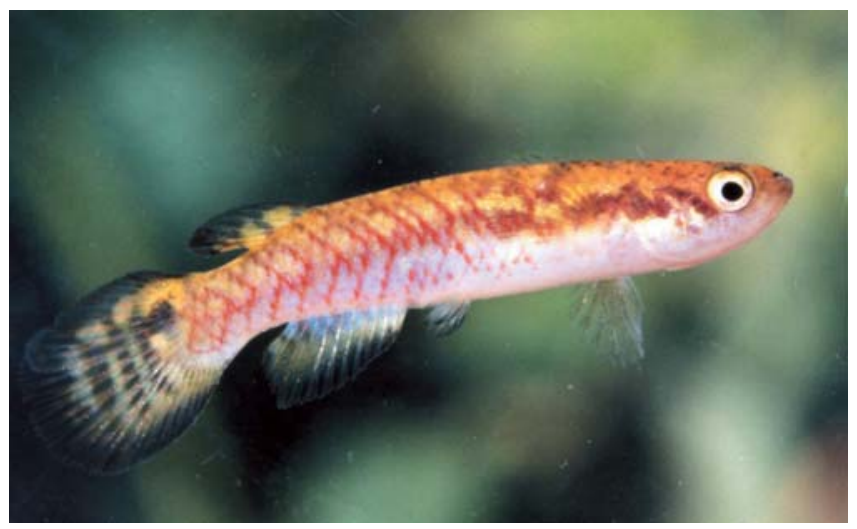

Fig. 7. Rivulus litteratus, UFRJ 5957, female, paratype, 25.6 mm SL (one day after collection); Brazil: Mato Grosso: Alto Araguaia. Photo by W. J. E. M. Costa.
Description. Morphometric data in Table 4. Largest specimen $30.2 \mathrm{~mm}$ SL, female. Dorsal profile slightly convex from snout to end of dorsal-fin base, approximately straight on caudal peduncle. Ventral profile convex on head, almost straight from anterior portion of venter to end of anal-fin base, nearly straight to slightly concave along caudal peduncle. Body slender, subcylindrical anteriorly, slightly deeper than wide, to compressed posteriorly. Greatest body depth at level of pelvic-fin base.

Dorsal and anal fins gently pointed in male, rounded in female. Caudal fin almost circular. Pectoral fin rounded, posterior margin on vertical anterior to pelvic-fin base. Tip of pelvic fin reaching base of first or second anal-fin ray in male, and vertical anterior to anus in female. Pelvic-fin bases in close proximity. Dorsal-fin origin on vertical through base of 7 th or 8th anal-fin ray, and between neural spines of 18 th and 19 th vertebrae. Anal-fin origin between pleural ribs of 13th and 15th vertebrae. Dorsal-fin rays 9-10; anal-fin rays 13-14; caudal-fin rays 31-33; pectoral-fin rays 13; pelvic- fin rays 7 .

Scales large, cycloid. Trunk scaled; head scaled except on its anteroventral surface. Body scales slightly extending over caudal-fin base; no scales on dorsal and anal fins. Frontal squamation F-patterned; E-scales not overlapping medially; scales arranged in circular pattern around central Ascale without exposed margins. Longitudinal series of scales 31-32; transverse series of scales 8; scale rows around caudal peduncle 16. Contact organs absent. Supraorbital neuromasts $3+3$. Six branchiostegal rays. Gill rakers of first branchial arch $1+7-8$. Three or four vomerine teeth. Total vertebrae 29-30.

Coloration. Male: Side of body metallic green, purplish blue above anal fin, with overlapped red marks of variable shapes, including chevron-like oblique bars with anteriorly directed vertex, horizontal rows of spots, and narrow and short zigzag stripes; sometimes, midlateral dark greenish gray zone, between humeral region and vertical through dorsal fin origin, when exposed to light. Anterior dorsolateral portion of flank greenish golden. Dorsum light yellowish brown with faint brown spots, venter white. Opercular region golden with two oblique dark red bars. Red marks on opercle and humeral region becoming dark reddish brown when exposed to light. Infraorbital region and ventral surface of head white. Lower jaw reddish gray. Iris light yellow. Dorsal fin yellow with four or five narrow red bars. Anal fin light yellow, base blue with five short red bars. Caudal fin yellow with five to seven red bars crossing fin except on ventral portion. Pelvic fin pale yellow. Pectoral fin hyaline.

Female: Side of body pale metallic green, purplish blue above anal fin, with narrow, coalesced red chevron-like oblique bars with anteriorly directed vertex; brown blotch on humeral region. Anterior dorsolateral portion of flank pale greenish golden. Dorsum light yellowish brown with brown dots, venter white. Opercular region pale golden with two oblique brown bars. Brown marks on opercle and humeral region becoming darker when exposed to light. 
Table 4. Morphometric data of the holotype (H, UFRJ 5956, male) and paratypes (UFRJ 5837) of Rivulus litteratus.

\begin{tabular}{|c|c|c|c|c|c|c|c|c|c|c|}
\hline \multirow[b]{2}{*}{ Standard length (mm) } & $\mathrm{H}$ & \multicolumn{4}{|c|}{ Males } & \multicolumn{5}{|c|}{ Females } \\
\hline & 26.7 & 24.1 & 23.4 & 23.1 & 21.9 & 24.3 & 22.7 & 22.3 & 21.8 & 21.7 \\
\hline \multicolumn{11}{|c|}{ Percents of standard length } \\
\hline Body depth & 21.8 & 22.8 & 22.7 & 23.3 & 22.9 & 22.7 & 22.2 & 23.3 & 21.4 & 22.2 \\
\hline Caudal peduncle depth & 14.5 & 14.5 & 14.7 & 14.7 & 14.3 & 13.9 & 15.0 & 13.9 & 13.1 & 13.6 \\
\hline Predorsal length & 75.9 & 76.0 & 76.1 & 76.5 & 77.4 & 77.6 & 76.9 & 77.9 & 77.3 & 76.2 \\
\hline Prepelvic length & 56.3 & 56.3 & 55.5 & 56.3 & 56.6 & 57.1 & 55.9 & 58.6 & 55.6 & 55.8 \\
\hline Length of dorsal-fin base & 13.5 & 12.6 & 12.9 & 13.8 & 15.6 & 12.5 & 12.6 & 11.5 & 12.3 & 12.3 \\
\hline Length of anal-fin base & 21.7 & 19.5 & 21.5 & 22.1 & 21.3 & 20.5 & 20.9 & 17.9 & 20.1 & 20.6 \\
\hline Caudal-fin length & 38.0 & 36.6 & 35.8 & 35.3 & 38.8 & 33.5 & 33.9 & 34.0 & 34.1 & 36.2 \\
\hline Pectoral-fin length & 22.6 & 21.2 & 19.5 & 21.1 & 22.2 & 20.1 & 20.7 & 19.0 & 19.5 & 19.4 \\
\hline Pelvic-fin length & 12.4 & 10.8 & 11.6 & 12.8 & 11.7 & 8.3 & 7.8 & 7.7 & 8.2 & 9.3 \\
\hline Head length & 28.3 & 28.7 & 27.2 & 27.6 & 28.7 & 27.9 & 27.2 & 27.3 & 26.7 & 28.3 \\
\hline \multicolumn{11}{|c|}{ Percents of head length } \\
\hline Head depth & 69.5 & 66.2 & 68.7 & 72.3 & 68.5 & 68.9 & 70.9 & 73.2 & 70.1 & 67.1 \\
\hline Head width & 73.4 & 70.4 & 69.3 & 75.5 & 71.0 & 75.8 & 74.9 & 76.2 & 73.7 & 72.5 \\
\hline Snout length & 13.7 & 14.1 & 14.2 & 13.3 & 15.0 & 13.1 & 13.8 & 13.2 & 13.9 & 13.8 \\
\hline Lower jaw length & 22.1 & 18.0 & 18.1 & 18.8 & 19.3 & 19.0 & 18.4 & 21.2 & 19.2 & 20.0 \\
\hline Eye diameter & 34.3 & 32.2 & 35.3 & 34.0 & 37.4 & 37.6 & 35.1 & 35.4 & 36.4 & 33.9 \\
\hline
\end{tabular}

Infraorbital region and ventral surface of head white. Lower jaw reddish gray. Iris light yellow. Dorsal fin yellow with four dark gray bars; broad dark gray to black distal stripe. Anal fin light yellow, base blue with five short red bars; broad dark gray to black distal stripe. Caudal fin light yellow with four or five dark gray bars; sometimes parts of some bars broken forming elongate spots; black spot on subdorsal portion of caudal fin base; dark gray stripe posterior to black spot, sometimes inconspicuous; caudal fin margins black. Pelvic fin pale yellow, anterior margin dark gray to black. Pectoral fin yellowish hyaline.

Distribution. Upper rio Araguaia basin, central Brazil (Fig. 2).

Etymology. From the Latin litteratus (marked with letters), an allusion to the color pattern of the males, comprising red marks on the flank resembling letters.

\section{Rivulus rutilicaudus, new species} Figs. 8-9

Rivulus pictus (non Costa, 1989). - Costa, 1995a: 216 (misidentification, specimens from Mineiros).

Holotype. UFRJ 5965, male, 22.9 mm SL; Brazil: Estado de Goiás: Município de Serranópolis, rio Verde floodplains, rio Paraná basin, road BR-060, 18²2'31.5”S 520'59.5”W, altitude $531 \mathrm{~m}$; by W. J. E. M. Costa, B. B. Costa and C. P. Bove, 15 January 2004.

Paratypes. Brazil: Estado de Goiás: rio Verde drainage, rio Paraná basin: UFRJ 5966, 4 males, 15.8-20.9 mm SL, 4 females, 15.4-22.8 mm SL, 3 juveniles of undetermined sex, 11.5-15.1 mm SL; MCP 36124; 1 male, 16.3 mm SL, 1 female, 15.4 mm SL; UFRJ 5967, 2 males, 17.5-17.6 mm SL, 1 female, 18.5 mm SL (c\&s); collected with the holotype.

Additional material (non type specimens). UFRJ 2208, 9 ex.; stream tributary to the upper rio Verde drainage, rio Paraná basin, road BR-364, $19 \mathrm{~km}$ SE from the city of Mineiros,
Município de Mineiros; W. J. E. M. Costa, A. Sarraf, R. D’Arrigo and G. Carvalho, 16 Sep 1994.

Diagnosis. Distinguished from its congeners in possessing a dark orangish red caudal fin in females ( $v s$. caudal fin hyaline or pale colored). Also distinguished from all other species of the $R$. punctatus group by the following combination of features: 10-12 dorsal fin rays (vs. 8-10), 34-35 scales on the longitudinal series (vs. 29-31), dorsal-fin origin at vertical between base of eighth and ninth anal-fin ray ( $v s$. between base of seventh and eighth or ninth and eleventh anal-fin ray), frontal squamation E-patterned ( $v s$. F-patterned), flank with striking iridescent colors in male, contrasting metallic blue to greenish blue on middle of flank with light purplish blue above anal fin and brownish golden on anterior dorsolateral portion of body ( $v s$. never a similar color pattern), flank with narrow pale red chevron-like oblique bars with anteriorly directed vertex ( $v s$. never a similar pattern), and no distinctive dark stripe along midline of flank ( $v s$. stripe present).

Description. Morphometric data in Table 5. Largest specimen $22.9 \mathrm{~mm}$ SL, male. Dorsal profile slightly convex from snout to end of dorsal-fin base, approximately straight to slightly concave on caudal peduncle. Ventral profile convex on head, weakly convex from anterior portion of venter to end of analfin base, nearly straight to gently concave along caudal peduncle. Body slender, subcylindrical anteriorly, slightly deeper than wide, to compressed posteriorly. Greatest body depth at level of pelvic-fin base.

Dorsal and anal fins weakly pointed to rounded in male, rounded in female. Caudal fin almost circular. Pectoral fin rounded, posterior margin on vertical just anterior to pelvicfin base. Tip of pelvic fin reaching urogenital papilla in male, and anus in female. Pelvic-fin bases in close proximity. Dorsal-fin origin on vertical through base of 8th or 9th anal-fin ray, and between neural spines of 17th and 19th vertebrae. Anal-fin origin between pleural ribs of 13th and 15th vertebrae. Dorsal-fin rays 10-12; anal-fin rays 14-5; caudal-fin rays 32-34; pectoral-fin rays 12-13; pelvic-fin rays 7 . 


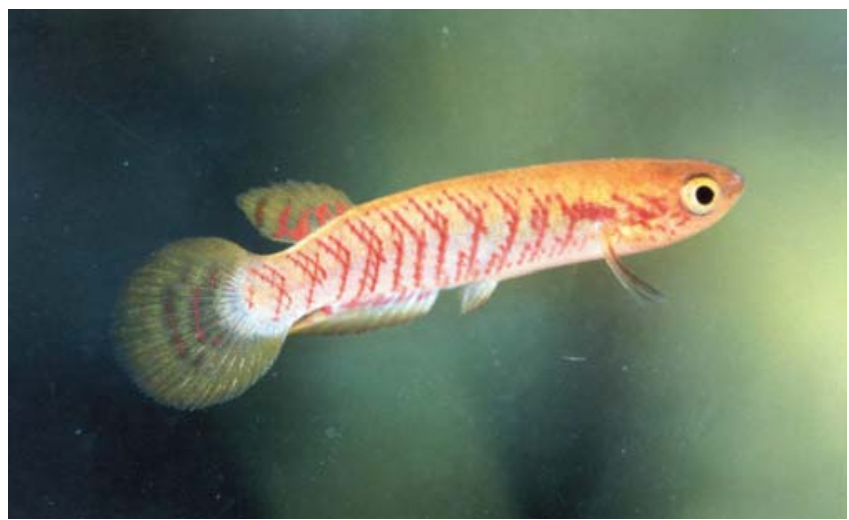

Fig. 8. Rivulus rutilicaudus, UFRJ 5965, male, holotype, 22.9 mm SL (one day after collection); Brazil: Goiás: Serranópolis. Photo by W. J. E. M. Costa.

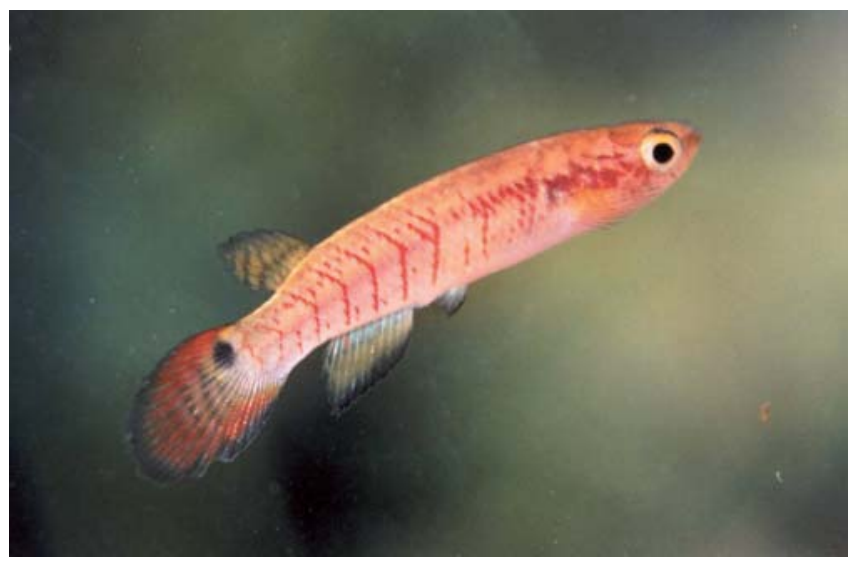

Fig. 9. Rivulus rutilicaudus, UFRJ 5966, female, paratype, $22.8 \mathrm{~mm}$ SL (one day after collection); Brazil: Goiás: Serranópolis. Photo by W. J. E. M. Costa.

Scales large, cycloid. Trunk scaled; head scaled except on its anteroventral surface. Body scales slightly extending over caudal-fin base; no scales on dorsal and anal fins. Frontal squamation E-patterned; E-scales not overlapping medially; scales arranged in circular pattern around central A-scale without exposed margins. Longitudinal series of scales 3435; transverse series of scales 10; scale rows around caudal peduncle 16. Contact organs absent. Supraorbital neuromasts $3+3$. Six branchiostegal rays. Gill rakers of first branchial arch $1+7$. Two vomerine teeth. Total vertebrae 29-30.

Coloration. Male: Side of body light metallic blue to light greenish blue, with narrow red chevron-like oblique bars with anteriorly directed vertex; rectangular dark red blotch on humeral region. Anterior dorsolateral portion of flank light brownish golden. Dorsum light yellowish brown, venter white. Opercular region light golden with two oblique dark red bars. Opercular and humeral red marks becoming brown when exposed to light. Infraorbital region and ventral surface of head white. Lower jaw gray. Iris light yellow. Dorsal fin yellow with five faint red bars. Anal fin pale yellow, base white to pale blue with six short red bars. Caudal fin yellow with four or five red bars on middle. Pelvic fin pale yellow. Pectoral fin yellowish hyaline.

Female: Side of body pale metallic greenish blue, with narrow red chevron-like oblique bars with anteriorly directed vertex; dark red blotch on humeral region. Anterior dorsolateral portion of flank pale golden. Dorsum light brown with gray blotches, venter white. Opercular region pale golden with two oblique dark red bars and blotches. Dark red marks on opercle and anterior portion of flank becoming black when exposed to light. Infraorbital region and ventral surface of head white. Lower jaw reddish gray. Iris light yellow. Dorsal fin dark yellow with three dark gray bars; broad dark gray distal stripe. Anal fin light yellow, base light blue with red dots; broad dark gray distal stripe. Caudal fin dark orangish red with four or five dark gray bars on middle; margins dark gray; black spot on subdorsal portion of caudal fin base. Pelvic fin pale blue, anterior margin dark gray. Pectoral fin hyaline.

Distribution. rio Verde drainage, rio Paraná basin, central Brazil (Fig. 2). Rio Verde here assigned is a right affluent to the rio Paraná, situated between rio Correntes and rio Claro, Estado de Goiás.

Etymology. From the Latin rutilis (bright red, rufous) and caudus (tail), in reference to the diagnostic orangish red caudal fin in females.

Table 5. Morphometric data of the holotype (H, UFRJ 5965, male) and paratypes (UFRJ 5966) of Rivulus rutilicaudus.

\begin{tabular}{|c|c|c|c|c|}
\hline \multirow[b]{2}{*}{ Standard length (mm) } & \multirow{2}{*}{$\begin{array}{c}\mathrm{H} \\
22.9\end{array}$} & \multirow{2}{*}{$\begin{array}{c}\text { Male } \\
20.9\end{array}$} & \multicolumn{2}{|c|}{ Females } \\
\hline & & & 22.8 & 20.2 \\
\hline \multicolumn{5}{|c|}{ Percents of standard length } \\
\hline Body depth & 22.7 & 22.1 & 21.9 & 21.7 \\
\hline Caudal peduncle depth & 14.6 & 13.7 & 13.7 & 13.5 \\
\hline Predorsal length & 76.1 & 76.3 & 77.9 & 75.9 \\
\hline Prepelvic length & 55.7 & 53.2 & 58.6 & 54.8 \\
\hline Length of dorsal-fin base & 14.5 & 13.0 & 11.2 & 12.8 \\
\hline Length of anal-fin base & 23.5 & 21.9 & 18.4 & 18.3 \\
\hline Caudal-fin length & 35.2 & 34.7 & 38.2 & 38.9 \\
\hline Pectoral-fin length & 20.2 & 20.2 & 19.8 & 20.8 \\
\hline Pelvic-fin length & 11.8 & 11.1 & 9.6 & 9.8 \\
\hline Head length & 28.2 & 28.2 & 28.6 & 28.2 \\
\hline \multicolumn{5}{|c|}{ Percents of he ad length } \\
\hline Head depth & 66.4 & 67.6 & 71.6 & 70.3 \\
\hline Head width & 68.8 & 71.6 & 72.4 & 72.2 \\
\hline Snout length & 12.6 & 12.6 & 13.2 & 11.4 \\
\hline Lower jaw length & 15.5 & 15.3 & 19.0 & 17.8 \\
\hline Eye diameter & 33.2 & 36.0 & 34.7 & 37.3 \\
\hline
\end{tabular}

\section{Rivulus scalaris, new species}

Fig. 10

Rivulus apiamici (non Costa, 1989). - Lacerda, 1989: 23 (misidentification, specimens from the upper rio Sucuruí drainage). 


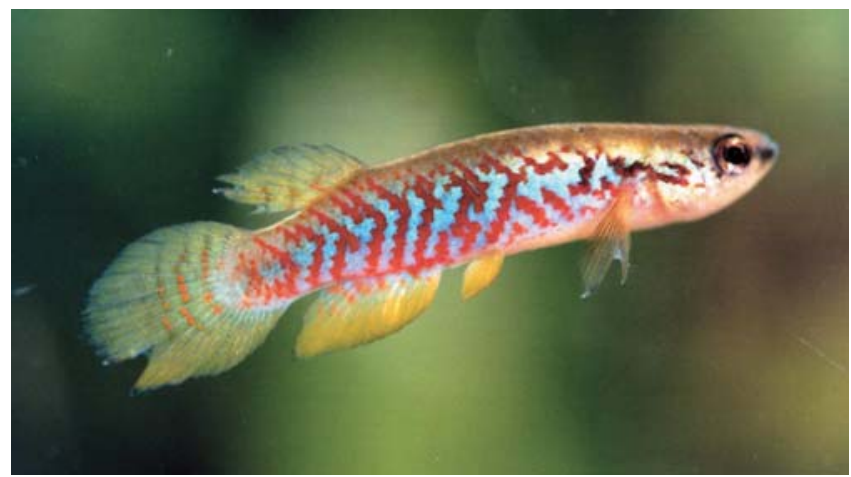

Fig. 10. Rivulus scalaris, UFRJ 5968, male, holotype, $26.8 \mathrm{~mm}$ SL (one day after collection); Brazil: Mato Grosso do Sul: Costa Rica. Photo by W. J. E. M. Costa.

Rivulus pictus (non Costa, 1989). - Costa, 1995a: 216 (misidentification, specimens from the rio Sucuruí and rio Aporé drainages).

Holotype. UFRJ 5968, male, 26.8 mm SL; Brazil: Estado de Mato Grosso do Sul: Município de Costa Rica, stream tributary to the upper rio Sucuruí drainage, rio Paraná basin, 1853'54.7'S 5258'44.2”'W, altitude 810 m; W. J. E. M. Costa, B. B. Costa and C. P. Bove, 13 Jan 2004.

Paratypes. Brazil: Estado de Mato Grosso do Sul, rio Paraná basin, rio Sucuruí drainage. UFRJ 5969, 8 males, 18.9-28.9 mm SL, 11 females, 17.9-31.5 mm SL; MCP 36125, 2 males, 20.520.9 mm SL, 3 females, 22.0-23.9 mm SL; UFRJ 5970, 2 males, 22.4-22.6 mm SL, 2 females, 19.2-24.6 mm SL; with the holotype. UFRJ 2277, 3 males, 20.6-25.6, 2 females, 22.3-26.5; UFRJ 2278, 2 males, 22.6-24.3, 2 females, 23.5-23.9 (c\&s); Ribeirão São Luiz, road MS-306; G. C. Brasil and M. T. C. Lacerda, 22 Jan 1988.

Additional material (non type specimens). Brazil: Estado de Mato Grosso do Sul, rio Paraná basin, rio Aporé drainage: UFRJ 2209, 17 ex.; stream tributary to rio Aporé, $68 \mathrm{~km} \mathrm{NW}$ from Cassilândia; W. J. E. M. Costa, A. Sarraf, R. D’Arrigo and G. Carvalho, 17 Sep 1994. UFRJ 2276, 10 ex.; road between Paranaíba and Cassilândia; G. C. Brasil and M. T. C. Lacerda, 21 Jan 1988. UFRJ 2207, 20 ex.; UFRJ 2280, 3 ex. (c\&s); swamp close to ribeirão Grande, road MS-306, 29 km SE from the city of Cassilândia, Município de Cassilândia; W. J. E. M. Costa, A. Sarraf, R. D'Arrigo and G. Carvalho, 17 Sep 1994. Estado de Goiás, rio Paraná basin, rio Correntes drainage: UFRJ 5387, 2 ex.; upper section of rio Formoso; W. J. E. M. Costa, S. M. Lima and A. C. Bacellar, 31 Mar 1999. Estado de Mato Grosso: MZUSP 73354, 15 ex.; stream tributary to rio Taquari, rio Paraguay basin, km 421.07 of the Ferronorte railway; C. L. R. Moreira and F. C. T. Lima, 22 May 2001.

Diagnosis. Differs from all other species of the $R$. punctatus group by the color pattern of adult males, consisting of flank intense metallic blue with small red squares aligned to form broad red chevron-like oblique bars ( $v s$. never a similar color pattern). It may be also distinguished from other species of the $R$. punctatus group by the combination of the following features: 10-12 dorsal fin rays (vs. 8-10), 32-34 scales on the longitudinal series (vs. 29-31), frontal squamation E-patterned (vs. F-patterned), 29-31 vertebrae (vs. 31-33), dorsal-fin origin at vertical between base of seventh and eighth anal-fin ray (vs. between base of eighth and eleventh ray), flank with intense iridescent colors in male, contrasting metallic blue to greenish blue on middle of flank with light purplish blue above anal fin and brownish golden on anterior dorsolateral portion of body ( $v s$. never a similar color pattern), and no distinctive dark stripe along midline of flank ( $v s$. stripe present).

Description. Morphometric data in Table 6. Largest specimen $31.5 \mathrm{~mm}$ SL, female. Dorsal profile slightly convex from snout to end of dorsal-fin base, approximately straight to slightly concave on caudal peduncle. Ventral profile convex on head, almost straight from anterior portion of venter to end of anal-fin base, nearly straight along caudal peduncle. Body slender, subcylindrical anteriorly, slightly deeper than wide, to compressed posteriorly. Greatest body depth at level of pelvic-fin base.

Dorsal and anal fins slightly pointed in male, rounded in female. Caudal fin rounded, almost circular. Pectoral fin rounded, posterior margin on vertical just anterior to pelvicfin base. Tip of pelvic fin reaching between base of 1st and 3rd anal-fin ray in male, and anus in female. Pelvic-fin bases in close proximity. Dorsal-fin origin on vertical through base of 7 th or 8th anal-fin ray, and between neural spines of 18th and 20th vertebrae. Anal-fin origin between pleural ribs of 13 th and 16 th vertebrae. Dorsal-fin rays 10-12; anal-fin rays 12-14; caudal-fin rays 31-33; pectoral-fin rays $12-13$; pelvicfin rays 7 .

Scales large, cycloid. Trunk scaled; head scaled except on its anteroventral surface. Body scales slightly extending over caudal-fin base; no scales on dorsal and anal fins. Frontal squamation E-patterned; E-scales not overlapping medially; scales arranged in circular pattern around central A-scale without exposed margins. Longitudinal series of scales 3234 ; transverse series of scales 8; scale rows around caudal peduncle 16. Contact organs absent. Supraorbital neuromasts $3+3$. Six branchiostegal rays. Gill rakers of first branchial arch $1+7$. Two vomerine teeth. Total vertebrae 29-31.

Coloration. Male: Side of body intense metallic blue to metallic greenish blue anteriorly and purplish blue ventrally, with broad red chevron-like oblique bars with anteriorly directed vertex, sometimes with red spots and vertical red lines between oblique bars; dark red spots on humeral region. Chevron-like bars of flank formed by small aligned square spots, resulting in indented posterior margin of bars in larger specimens. Anterior dorsolateral portion of flank light brownish golden. Dorsum light yellowish brown, venter white. Opercular region golden with two oblique dark red bars. Opercular and humeral red marks becoming black when exposed to light. Infraorbital region and ventral surface of head white. Lower jaw gray. Iris light yellow, anterior and posterior portion dark 
Table 6. Morphometric data of the holotype (H, UFRJ 5968, male) and paratypes (UFRJ 5969) of Rivulus scalaris.

\begin{tabular}{|c|c|c|c|c|c|c|c|c|c|c|}
\hline \multirow[b]{2}{*}{ Standard length (mm) } & \multirow{2}{*}{$\begin{array}{c}\mathrm{H} \\
26.8\end{array}$} & \multicolumn{4}{|c|}{ Males } & \multicolumn{5}{|c|}{ Females } \\
\hline & & 28.9 & 24.7 & 23.7 & 22.3 & 31.5 & 29.4 & 24.3 & 24.2 & 24.1 \\
\hline \multicolumn{11}{|c|}{ Percents of standard length } \\
\hline Body depth & 23.6 & 23.7 & 23.0 & 22.5 & 23.6 & 22.5 & 22.9 & 22.7 & 25.2 & 23.2 \\
\hline Caudal peduncle depth & 14.4 & 14.5 & 14.2 & 13.8 & 14.6 & 13.3 & 13.8 & 13.5 & 13.8 & 13.5 \\
\hline Predorsal length & 73.0 & 74.0 & 74.0 & 74.3 & 75.0 & 76.2 & 78.7 & 73.6 & 75.7 & 73.9 \\
\hline Prepelvic length & 58.3 & 56.8 & 57.9 & 55.6 & 56.7 & 55.3 & 55.9 & 59.2 & 56.3 & 58.7 \\
\hline Length of dorsal-fin base & 14.2 & 11.2 & 13.6 & 12.2 & 12.6 & 11.4 & 10.6 & 10.8 & 11.3 & 12.3 \\
\hline Length of anal-fin base & 18.6 & 21.0 & 19.6 & 18.1 & 20.2 & 17.4 & 18.5 & 16.2 & 17.8 & 16.9 \\
\hline Caudal-fin length & 36.3 & 35.9 & 32.7 & 36.4 & 36.2 & 31.8 & 30.6 & 33.2 & 34.5 & 33.6 \\
\hline Pectoral-fin length & 21.5 & 21.1 & 20.8 & 20.0 & 20.9 & 19.4 & 18.6 & 19.6 & 20.4 & 18.8 \\
\hline Pelvic-fin length & 13.0 & 13.6 & 13.7 & 13.1 & 13.0 & 8.4 & 8.7 & 9.6 & 9.9 & 8.7 \\
\hline Head length & 27.1 & 27.0 & 28.3 & 27.1 & 29.1 & 25.9 & 26.8 & 27.4 & 28.3 & 26.3 \\
\hline \multicolumn{11}{|c|}{ Percents of head length } \\
\hline Head depth & 68.7 & 72.8 & 67.3 & 74.3 & 67.3 & 72.1 & 74.2 & 73.1 & 76.6 & 72.7 \\
\hline Head width & 71.9 & 72.0 & 69.2 & 74.4 & 70.6 & 77.3 & 76.2 & 73.6 & 78.0 & 79.2 \\
\hline Snout length & 14.0 & 14.2 & 14.0 & 14.4 & 12.8 & 14.8 & 15.1 & 13.8 & 15.5 & 14.8 \\
\hline Lower jaw length & 20.5 & 21.6 & 17.9 & 18.7 & 16.5 & 20.1 & 20.2 & 19.4 & 18.3 & 18.5 \\
\hline Eye diameter & 33.2 & 32.7 & 33.1 & 34.9 & 33.6 & 30.6 & 31.4 & 34.5 & 33.7 & 37.9 \\
\hline
\end{tabular}

brown. Dorsal fin yellow with four faint red bars. Anal fin bright yellow, base pale blue with six short red bars. Caudal fin yellow with five to seven narrow pale red bars. Pelvic fin bright yellow. Pectoral fin yellowish hyaline.

Female: Side of body pale metallic greenish blue, with red chevron-like oblique bars with anteriorly directed vertex; small dark red blotch on humeral region. Anterior dorsolateral portion of flank pale golden. Dorsum light brown with pale gray dots, venter white. Opercular region pale golden with two oblique dark red bars. Dark red marks on opercle and anterior portion of flank becoming black when exposed to light. Infraorbital region and ventral surface of head white. Lower jaw gray. Iris light yellow. Dorsal fin pale yellow with two dark gray bars; dark gray distal stripe. Anal fin light yellow, base light blue with red dots; dark gray distal stripe. Caudal fin pale yellow with three to six gray bars; margins dark gray; black spot on subdorsal portion of caudal fin base. Pelvic fin pale yellow, anterior margin gray. Pectoral fin hyaline.

Distribution. rio Sucuruí, rio Aporé and upper rio Correntes drainages, rio Paraná basin, and upper rio Taquari drainage, rio Paraguay basin, central Brazil (Fig. 2).

Etymology. From the Latin scalaris (with a stair), referring to the color pattern of males consisting of red oblique bars with indented posterior borders, resembling small squares aligned to form stairs.

\section{Rivulus egens, new species}

Fig. 11

Holotype. UFRJ 5973, male, 25.2 mm SL; Brazil: Estado de Mato Grosso do Sul: Município de Camapuã, road BR-060, rio São Domingos, upper rio Verde drainage, rio Paraná basin, 19¹9'26.0”'S 5321'6.8”W, altitude 532 m; W. J. E. M. Costa, B. B. Costa and C. P. Bove, 12 Jan 2004.

Paratypes. UFRJ 5974, 4 males, 15.0-26.0 mm SL, 110 females,
14.1-22.8 mm SL; MCP 36126, 3 females, 17.1-18.3 mm SL; UFRJ 5975, 1 male, 21.2 mm SL, 2 females, 19.1-19.4 mm SL (c\&s); collected with the holotype.

Additional material (non type specimens). UFRJ 6009, 2; Brazil: Mato Grosso do Sul: Campo Grande, upper rio Inhanduí drainage, rio Paraná basin; A. Rosso, 13 Mar 2004. UFRJ 6010, 1; UFRJ 6011, 5 (c\&s); same locality and collector, 30 Mar 2004.

Diagnosis. Differs from all other species of the R. punctatus group by the combination of the following features: frontal squamation E-patterned (vs. F-patterned), 9-10 dorsal fin rays (vs. 10-12), 30-31 scales on the longitudinal series ( $v s$. 32-36), 13-14 pectoral fin rays (vs. 11-12), flank with striking iridescent colors in male, contrasting metallic blue to greenish blue on middle of flank with light purplish blue above anal fin and brownish golden on anterior dorsolateral portion of body ( $v s$. never a similar color pattern), flank with narrow pale red chevron-like oblique bars with anteriorly directed vertex ( $v s$. never a similar pattern), no distinctive dark stripe along midline of flank ( $v s$. stripe present), caudal and anal fins without red marks in males ( $v s$. red marks present), and caudal fin with vertical rows of dark gray spots in females ( $v s$. dark gray bars).

Description. Morphometric data in Table 7. Largest specimen $26.0 \mathrm{~mm}$ SL, male. Dorsal profile slightly convex from snout to end of dorsal-fin base, approximately straight to weakly concave on caudal peduncle. Ventral profile convex on head, slightly convex to almost straight from anterior portion of venter to end of anal-fin base, nearly straight along caudal peduncle. Body slender, subcylindrical anteriorly, slightly deeper than wide, to compressed posteriorly. Greatest body depth at level of pelvic-fin base.

Dorsal and anal fins gently pointed in male, rounded in female. Caudal fin rounded, almost circular. Pectoral fin rounded, posterior margin on vertical through pelvic-base in male, just anterior to it in female. Tip of pelvic fin reaching base of 2 nd anal-fin ray in male, and anus in female. Pelvic-fin 
bases in close proximity. Dorsal-fin origin on vertical through base of 9th anal-fin ray, and between neural spines of 19th and 20th vertebrae. Anal-fin origin between pleural ribs of 13 th and 15 th vertebrae. Dorsal-fin rays 9-10; anal-fin rays 13-14; caudal-fin rays 30-31; pectoral-fin rays 13-14; pelvicfin rays 7 .

Scales large, cycloid. Trunk scaled; head scaled except on its anteroventral surface. Body scales slightly extending over caudal-fin base; no scales on dorsal and anal fins. Frontal squamation E-patterned; E-scales not overlapping medially; scales arranged in circular pattern around central A-scale without exposed margins. Longitudinal series of scales 3031 ; transverse series of scales 8 ; scale rows around caudal peduncle 16. Contact organs absent. Supraorbital neuromasts $3+3$. Six branchiostegal rays. Gill rakers of first branchial arch $1+7$. Two vomerine teeth. Total vertebrae 29-30.

Coloration. Male: Side of body metallic blue to greenish blue, with red chevron-like oblique bars with anteriorly directed vertex; small dark red spots on humeral region. Anterior dorsolateral portion of flank pale brownish golden. Dorsum light yellowish brown, venter white. Opercular region silver with two faint oblique dark red to brown bars. Opercular and humeral marks becoming black when exposed to light. Infraorbital region and ventral surface of head white. Lower jaw dark gray. Iris light yellow. Dorsal fin yellow with three narrow orange bars. Anal fin yellow, base light blue; narrow black distal margin. Caudal fin yellow with dark orange line along margins. Pelvic fin pale yellow. Pectoral fin hyaline, distal portion gray.

Female: Side of body pale greenish golden, with narrow red chevron-like oblique bars with anteriorly directed vertex; dark reddish brown spots on anterior portion of midlateral region. Anterior dorsolateral portion of flank pale golden. Dorsum light brown with dark gray spots, venter white. Opercular region silver with two oblique brown bars. Brown marks on opercle and anterior portion of flank becoming black when exposed to light. Infraorbital region and ventral surface of head white. Lower jaw dark reddish gray. Iris light yellow. Dorsal fin light greenish yellow with three rows of small dark gray spots; narrow dark gray distal stripe. Anal fin pale yellow, base light blue; dark gray distal stripe. Caudal fin light yellow, dorsal and ventral portions pale pink, with vertically elongated spots; margins dark gray; black spot on subdorsal portion of caudal fin base. Pelvic fin pale blue, anterior margin dark gray. Pectoral fin hyaline.

Distribution. Rio São Domingos, upper rio Verde drainage, rio Paraná basin, central Brazil (Fig. 2). Rio Verde here is a drainage situated between rio Pardo and rio Sucuruí drainages, Estado de Mato Grosso do Sul. Smaller specimens were collected in the upper rio Inhanduí drainage.

Etymology. From the Latin egens (poor), in reference to the color pattern in which dark marks are absent on the caudal fin of males.

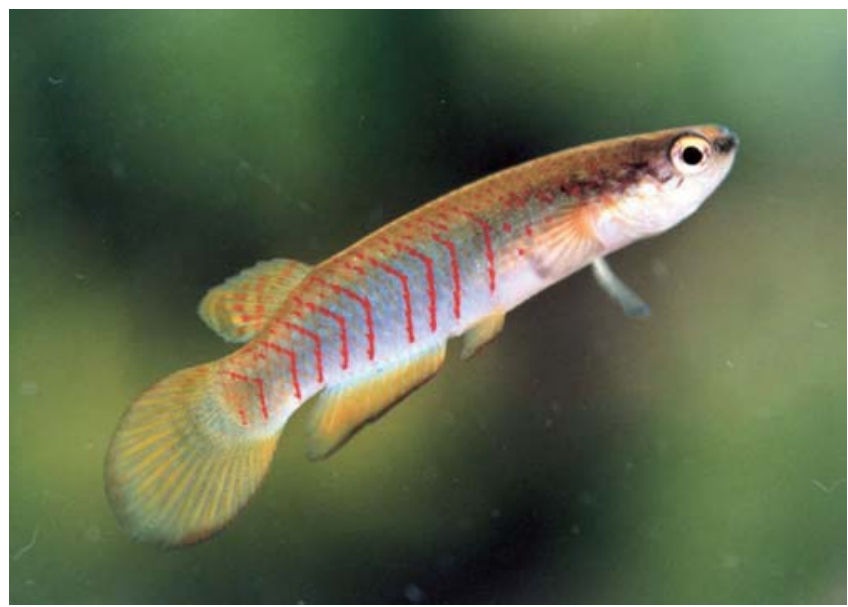

Fig. 11. Rivulus egens, UFRJ 5973, male, holotype, $25.2 \mathrm{~mm}$ SL (one day after collection); Brazil: Mato Grosso do Sul: Camapuã. Photo by W. J. E. M. Costa.

Table 7. Morphometric data of the holotype (H, UFRJ 5973, male) and paratypes (UFRJ 5974) of Rivulus egens.

\begin{tabular}{|c|c|c|c|c|c|c|}
\hline \multirow[b]{2}{*}{ Standard length $(\mathrm{mm})$} & \multirow{2}{*}{$\begin{array}{c}\mathrm{H} \\
25.2\end{array}$} & \multicolumn{3}{|c|}{ Males } & \multicolumn{2}{|c|}{ Females } \\
\hline & & 26.0 & 21.6 & 20.5 & 22.8 & 20.6 \\
\hline \multicolumn{7}{|c|}{ Percents of standard length } \\
\hline Body depth & 23.8 & 22.5 & 23.3 & 23.3 & 21.8 & 21.3 \\
\hline Caudal peduncle depth & 15.2 & 14.3 & 13.9 & 14.4 & 13.5 & 13.3 \\
\hline Predorsal length & 75.9 & 78.1 & 77.0 & 76.0 & 77.6 & 78.2 \\
\hline Prepelvic length & 54.7 & 54.2 & 52.8 & 55.6 & 56.8 & 56.7 \\
\hline Length of dorsal-fin base & 13.2 & 11.5 & 11.7 & 13.2 & 10.8 & 11.1 \\
\hline Length of anal-fin base & 23.0 & 20.8 & 21.0 & - & 19.8 & 19.8 \\
\hline Caudal-fin length & 38.3 & 33.4 & 38.5 & 35.2 & 32.3 & 34.9 \\
\hline Pectoral-fin length & 21.8 & 21.0 & 22.7 & 20.1 & 20.6 & 21.1 \\
\hline Pelvic-fin length & 13.4 & 12.9 & 8.1 & 11.5 & 9.0 & 10.0 \\
\hline Head length & 27.2 & 26.2 & 26.0 & 27.4 & 26.9 & 26.8 \\
\hline \multicolumn{7}{|c|}{ Percents of head length } \\
\hline Head depth & 69.2 & 68.1 & 69.0 & 67.9 & 69.2 & 67.6 \\
\hline Head width & 72.3 & 72.1 & 75.4 & 72.2 & 73.5 & 75.4 \\
\hline Snout length & 13.6 & 14.7 & 14.3 & 14.3 & 12.1 & 12.7 \\
\hline Lower jaw length & 17.8 & 17.2 & 20.5 & 17.6 & 17.9 & 17.0 \\
\hline Eye diameter & 33.1 & 33.8 & 36.4 & 35.5 & 34.0 & 35.1 \\
\hline
\end{tabular}

\section{Discussion}

Relationships among species of the $R$. punctatus group are presently unclear. Diagnostic characters here used to distinguish species assemblages within this group (see key above) are variable in other groups of Rivulus, making it difficult to establish polarization of character states without a broader phylogenetic analysis, which is beyond the scope of the present study. However, features of the color pattern found in some new taxa herein described are unique among rivulids, thus considered autapomorphies: caudal fin with entire marginal region dark orange with black ventral outline in males of $R$. dapazi, whole anal fin blue with oblique red bars in both sexes of $R$. cyanopterus, caudal fin hyaline with narrow light orange stripe on the dorsal and ventral margins in males of $R$. rossoi, flank with red marks variable in shape, 
highly overlapped, in males of $R$. litteratus, caudal fin dark orangish red in females of $R$. rutilicaudus, and flank intense metallic blue with small red squares aligned to form broad red chevron-like oblique bars in males of $R$. scalaris.

The number of species of the Rivulus punctatus group herein recognized suggests that it is highly diversified in the central Brazilian plateau, with each species endemic to a small area. This contrasts with species inhabiting the floodplains of the lowland rivers, such as $R$. punctatus and $R$. zygonectes, where a single species has a wide geographic distribution. This possibly is a result of a complex geologic history for the central Brazilian plateau making in the past populations isolated from congeners in streams draining karstic areas.

\section{Acknowledgements}

I am grateful to C. P. Bove and B. B. Costa for help in recent collecting trips. Thanks are due to R. C. da Paz, A. Rosso, C. Moreira, G. Brasil, and F. Lima for the loan or donation of specimens, to S. Lima, E. Araújo, D. Belote, A. Sarraf, G. Carvalho, and R. D'Arrigo for technical assistance in the field, to A. Felix for calling my attention to the occurrence of Rivulus in Jaciara, and to R. Reis for kindly making available the cartographic basis prepared by himself and J. P. da Silva. The manuscript benefited from the careful revision by two anonymous reviewers. This study was supported by CNPq (Conselho Nacional de Desenvolvimento Científico e Tecnológico - Ministério de Ciência e Tecnologia) and FAPERJ (Fundação de Amparo à Pesquisa do Estado do Rio de Janeiro). Material was collected with permits 02.022005956/02 from IBAMA (Instituto Brasileiro do Meio Ambiente e dos Recursos Naturais Renováveis - Ministério do Meio Ambiente, dos Recursos Hídricos e da Amazônia Legal).

\section{Literature Cited}

Costa, W. J. E. M. 1989. Descrição de cinco novas espécies de Rivulus das bacias dos rios Paraná e São Francisco (Cyprinodontiformes, Rivulidae). Revista Brasileira de Zoologia, 6:523-534.

Costa, W. J. E. M. 1995a. Revision of the Rivulus punctatus species-complex (Cyprinodotiformes: Rivulidae). Ichthyological Exploration of Freshwaters, 6:207-226.

Costa, W. J. E. M. 1995b. Pearl killifishes - the Cynolebiatinae: systematics and biogeography of the neotropical annual fish subfamily. Neptune City, TFH, 128p.

Costa, W. J. E. M. 1998. Phylogeny and classification of Rivulidae revisited: evolution of annualism and miniaturization in rivulid fishes (Cyprinodontiformes: Aplocheiloidei). Journal of Comparative Biology, 3:33-92.

Costa, W. J. E. M. 2001. The neotropical annual fish genus
Cynolebias (Cyprinodontiformes: Rivulidae): phylogenetic relationships, taxonomic revision and biogeography. Ichthyological Exploration of Freshwaters, 12:333-383.

Costa, W. J. E. M. 2003a. Family Rivulidae (South American annual fishes). Pp 526-548. In: Reis, R. E., S. O. Kullander $\&$ C. J. Ferraris, Jr. (Eds.). Check list of the freshwater fishes of South and Central America. Porto Alegre, Edipucrs, 729p.

Costa, W. J. E. M. 2003b. Rivulus paracatuensis n. sp. (Cyprinodontiformes: Rivulidae): a new rivuline species from the rio São Francisco basin, Brazil. Aqua Journal of Ichthyology and Aquatic Biology, 7:39-43.

Costa, W. J. E. M. 2003c. A new miniature rivuline fish from the upper Negro river basin, northern Brazil (Teleostei, Cyprinodontiformes, Rivulidae). Arquivos do Museu Nacional, Rio de Janeiro, 61:175-178.

Costa, W. J. E. M. 2003d. A new species of the genus Rivulus Poey, 1860 from the Parnaiba river basin, northeastern Brazil (Teleostei, Cyprinodontiformes, Rivulidae). Boletim do Museu Nacional, Rio de Janeiro, 511:1-7.

Costa, W. J. E. M. 2004a. Rivulus uakti sp. n. and $R$. amanapira sp. n. (Teleostei: Cyprinodontiformes: Rivulidae): two new species from the upper rio Negro, Brazilian Amazon. Zootaxa, 465:1-12.

Costa, W. J. E. M. 2004b. Rivulus kirovskyi, a new killifish from the central Amazon, Brazil (Cyprinodontiformes: Rivulidae). Neotropical Ichthyology, 2:9-12.

Costa, W. J. E. M. 2004c. Relationships and redescription of Fundulus brasiliensis (Cyprinodontiformes: Rivulidae), with description of a new genus and notes on the classification of the Aplocheiloidei. Ichthyological Exploration of Freshwaters, 15:105-120.

Costa, W. J. E. M., C. R. Moreira \& F. C. T. Lima. 2003. Simpsonichthys cholopteryx n. sp. (Cyprinodontiformes: Rivulidae: Cynolebiatinae): a new dwarf annual fish from the upper rio Araguaia basin, central Brazil. Aqua Journal of Ichthyology and Aquatic Biology, 6:139-144.

Hoedeman, J. J. 1958. Rivulid fishes of the Antilles. Studies on the Fauna of Curaçao and other Caribbean Islands, 32:112-127.

Lacerda, M. T. 1989. Araguaia: em busca de Cynolebias GO3. Revista de Aquariofilia, 9:20-29.

Taylor, W. R. \& G. C. Van Dyke. 1985. Revised procedures for staining and clearing small fishes and other vertebrates for bone and cartilage study. Cybium, 9:107-109.

Received May 2004

Accepted January 2005 